\title{
Side effects of carbenoxolone sodium: a study of ambulant therapy of gastric ulcer
}

\author{
R. D. MONTGOMERY \\ From the East Birmingham Hospital
}

EDITORIAL COMMENT Using $50 \mathrm{mg}$. three times a day, carbenoxolone sodium was found to be safe from side effects in normotensive patients without cardiac, renal, or hepatic disease.

Hypertension, oedema, or serious potassium loss has been reported in up to $50 \%$ of patients receiving carbenoxolone sodium, $300 \mathrm{mg}$. daily, for the treatment of gastric ulcer (Doll, Hill, Hutton, and Underwood, 1962; Doll, Hill, and Hutton, 1965; Turpie and Thomson, 1965; Horwich and Galloway, 1965). According to Turpie and Thomson's observations on 10 patients, these side effects can also occur with a dosage of $150 \mathrm{mg}$. daily for four weeks, and they concluded that carbenoxolone sodium should only be used when close clinical supervision and biochemical facilities are available.

This paper reports the effects on 50 out-patients treated with carbenoxolone sodium, $150 \mathrm{mg}$. daily for six weeks, as part of a long-term prospective study of the medical management of gastric ulcers based on this drug.

\section{METHOD}

All patients were included who presented with an apparently benign gastric ulcer demonstrable radiologically, in the absence of intractable haemorrhage, pyloric obstruction, severe hypertension, or heart failure. The average age of the subjects was 49 years, and six of them were over 65 . The length of history ranged from three weeks to 25 years with a mean of four years. Nine subjects had hypertension, with a resting diastolic blood pressure of 95 to $105 \mathrm{~mm}$. $\mathrm{Hg}$.

Carbenoxolone sodium was administered as $50 \mathrm{mg}$. tablets three times a day after meals for six weeks, commencing within two weeks of a barium meal. Clinical state, body weight, and blood pressure were recorded at intervals of three weeks, and a barium meal was repeated after six weeks. If an ulcer was still visible, the treatment was continued for another six weeks. Serum electrolytes and urea were estimated on the last day of treatment in 32 patients, and before treatment in 18 of these. One patient was withdrawn because he proved to have a gastric carcinoma.

The cases were treated as out-patients, and were not confined to bed, normal work and activities being permitted as soon as they were free of serious symptoms. The only dietary advice given was a restriction of cooked fats. Patients were also advised strongly, but not always effectively, to stop smoking. Every effort was made to ensure that the prescribed tablets were taken. No potassium supplements or diuretics were given.

\section{RESULTS}

Thirty-seven patients had an ulcer niche with a profile at least $10 \mathrm{sq} . \mathrm{mm}$. in area, on the lesser curve at or above the angulus. The effect on the niche in 30 of these cases is summarized in Table I; four are excluded from this analysis because they had periods of bed rest, two others defaulted from a repeat radiograph (all six were free of symptoms), and one died (see below).

In six weeks 13 ulcers $(43 \%)$ were radiologically healed and another four $(13 \%)$ almost healed, and the average reduction in profile area of the ulcer was $61 \%$. Eight patients $(27 \%)$ had persisting symptoms. Three of the latter (cases 11, 21, and 38), whose histories were longer than five years, were subjected to gastrectomy. Nine patients with a persisting niche received a further course of treatment, as did case 15 with persisting symptoms. After 12 weeks a niche was still demonstrable in seven cases, and one other (case 4) had symptoms and later showed radiological recurrence. Case 35, with eight years' history, was referred for surgery with severe symptoms at 10 weeks. Thus $18(60 \%)$ were 'healed' and symptomfree in 12 weeks.

\section{SIDE EFFECTS}

Apart from the group of 37 patients described above, the régime was applied to seven patients with gastric ulcers distal to the angulus, with niches not readily measurable, and to six patients with combined 
TABLE I

ULCER NICHE AREA (SQ. MM.) IN LESSER CURVE ULCERS (30 CASES)

\begin{tabular}{|c|c|c|c|}
\hline Case No. & Initial Area & After Six Weeks & After 12 Weeks \\
\hline 1 & 215 & 97 & 0 \\
\hline 2 & 40 & 0 & \\
\hline 4 & 57 & $34^{1}$ & $0^{1}$ \\
\hline 5 & 56 & 0 & \\
\hline 7 & 115 & 49 & 38 \\
\hline 9 & 11 & 0 & \\
\hline 10 & 29 & 20 & 25 \\
\hline 11 & 30 & $78^{1}$ & Gastrectomy \\
\hline 12 & 35 & 3 & 0 \\
\hline 14 & 94 & 0 & \\
\hline 15 & 61 & $0^{1}$ & $4^{1}$ \\
\hline 19 & 35 & 0 & \\
\hline 20 & 27 & 2 & 0 \\
\hline 21 & 36 & $40^{1}$ & Gastrectomy \\
\hline 22 & 46 & 0 & \\
\hline 28 & 10 & 3 & $4^{1}$ \\
\hline 31 & 14 & 0 & \\
\hline 32 & 17 & 0 & \\
\hline 34 & 10 & 0 & \\
\hline 35 & 27 & $6^{1}$ & Gastrectomy \\
\hline 36 & 21 & 0 & \\
\hline 37 & 32 & 15 & 0 \\
\hline 38 & 95 & $56^{1}$ & Gastrectomy \\
\hline 39 & 12 & 3 & 3 \\
\hline 41 & 11 & 14 & 7 \\
\hline 42 & 56 & $29^{1}$ & $62^{1}$ \\
\hline 44 & 65 & $0^{1}$ & \\
\hline 48 & 63 & 10 & 0 \\
\hline 49 & 22 & 0 & \\
\hline 51 & 47 & 17 & 0 \\
\hline
\end{tabular}

gastric and duodenal ulcers. Three of these had 12 weeks' treatment. Seven patients in all have relapsed after three months and received a further course of carbenoxolone sodium. Data are therefore available from 70 courses of six weeks' treatment given to 50 patients, and 13 of these received continuous treatment for 12 weeks.

Clinical side effects were observed in three cases ( $4 \%$ of the treatment courses), and are summarized in Table II. All three patients were in the group of nine who were initially hypertensive and all were over 60 years old.

TABLE II

DETAILS OF CLINICAL SIDE EFFECTS IN THREE CASES

\begin{tabular}{|c|c|c|c|c|c|c|}
\hline \multirow[b]{2}{*}{ Case No. } & \multirow[b]{2}{*}{ Age } & \multirow[b]{2}{*}{ Sex } & \multicolumn{2}{|c|}{$\begin{array}{l}\text { Blood Pressure } \\
(\mathrm{mm} . \mathrm{Hg})\end{array}$} & \multirow[b]{2}{*}{$\begin{array}{l}\text { Weight } \\
\text { Gain } \\
\text { (kg.) }\end{array}$} & \multirow[b]{2}{*}{ Other Features } \\
\hline & & & Initial & Final & & \\
\hline 3 & 63 & $\mathbf{F}$ & $160 / 105$ & $210 / 120$ & $4 \cdot 0$ & Ankle oedema \\
\hline 20 & 67 & $\mathrm{~F}$ & $160 / 95$ & $220 / 110$ & $2 \cdot 5$ & $\begin{array}{l}\text { Ankle oedema } \\
\text { and epistaxes }\end{array}$ \\
\hline 27 & 63 & $\mathbf{M}$ & $170 / 105$ & - & - & $\begin{array}{l}\text { Congestive failure } \\
\text { (fatal stroke } 10 \\
\text { days later) }\end{array}$ \\
\hline
\end{tabular}

In case 20 , increased hypertension and ankle oedema were recorded at the completion of six weeks' treatment and she complained of epistaxes. In case 3, the ulcer was unhealed at six weeks, oedema occurred after 11 weeks and hypertension was found to have increased. Case 27 developed mild congestive cardiac failure with oedema after only 10 days' carbenoxolone treatment. This was successfully treated at home by his family doctor and the blood pressure was not recorded. Carbenoxolone was discontinued and there were no further symptoms, but 10 days later he died of a cerebral haemorrhage. Unfortunately we have no evidence as to whether or not a sustained rise in blood pressure may have contributed to this patient's death.

In the remaining 47 patients, the individual changes of blood pressure were not obviously significant, but the overall trend was upward. Ten patients showed a pressure rise of 15 to $30 \mathrm{~mm}$. systolic and/or 10 to $15 \mathrm{~mm}$. diastolic, but five others showed a fall of the same order. The mean change in the whole series was $+7 \mathrm{~mm}$. systolic and + $4 \mathrm{~mm}$. diastolic.

No abnormalities were observed in serum sodium, chloride, or urea levels. The mean serum potassium level in 32 cases at the end of treatment was $4 \cdot 1$ $\mathrm{mEq} / \mathrm{l}$. In 18 consecutive patients in whom it was also estimated before treatment, the mean change was a fall of $0.3 \mathrm{mEq} . / 1$. These mean figures include case 47 , a man aged 63 with a giant ulcer, treated initially with bed rest, whose serum potassium level fell from $4 \cdot 1$ to $2.9 \mathrm{mEq}$./l. after six weeks' outpatient therapy. It was then discovered that he had been given prednisone $15 \mathrm{mg}$. daily from another source for treatment of arthritis. In one other patient the serum potassium level fell to $3.4 \mathrm{mEq} . / 1$., and in two others to $3.6 \mathrm{mEq}$./l. Three of these four patients showed a rise of blood pressure of 15 to $20 \mathrm{~mm}$. systolic and 10 to $15 \mathrm{~mm}$. diastolic, but none had oedema or suffered any ill effects.

No undue tendency to hypokalaemia was found in the patients who were initially hypertensive.

Two patients complained of heartburn, one of headache, and another of numbness and paraesthesiae of the extremities during the first two weeks of treatment, but this was continued and the symptoms disappeared. It is doubtful if the symptoms were due to the drug.

\section{DISCUSSION}

The findings suggest that carbenoxolone sodium in a dose of $150 \mathrm{mg}$. daily should be given only under very close supervision, if at all, to patients with any degree of hypertension. The same applies by 
inference to any patients with chronic cardiac, renal, or hepatic disease, and it should not be given in conjunction with steroid therapy. In other subjects no ill effects appear to accompany its use over a period of six weeks, nor, in a limited series, over a period of 12 weeks. In particular no serious loss of potassium was found. On this dose schedule it appears to be as safe a drug as many others which are freely prescribed in general practice.

It remains to be proved that carbenoxolone sodium in this dosage is of value in the treatment of gastric ulcer. The results after six weeks of ambulant treatment in this series, however, are similar to those of Doll et al. $(1962,1965)$ who used twice the dosage for four weeks, and compare favourably with their two control series on inert tablets, radiographed after five weeks (Table III).

\section{TABLE III}

RESULTS OF TREATMENT ASSESSED BY CHANGE OF SIZE OF ULCER IN THIS TRIAL AND OTHERS

$\begin{array}{ll} & \text { Percentage } \\ \text { Series } & \text { of Patients Average } \\ & \text { Showing } \\ & \text { Radiological Size of Ulcer (\%) } \\ & \text { "Healing' }\end{array}$

$\begin{array}{llrr}\text { Doll et al. (1962) } & \text { Carbenoxolone } & & \\ & 100 \text { mg. t.d.s. (30) } & 37 & 72 \\ & \text { Inert tablets (20) } & 5 & 35 \\ \text { Doll et al. (1965) } & \text { Carbenoxolone } & & 78 \\ & 100 \text { mg. t.d.s. (24) } & 42 & 39 \\ & \text { Inert tablets (22) } & 27 & \\ \text { Montgomery } & \text { Carbenoxolone } & & 61^{2} \\ \text { (present series) } & 50 \text { mg. t.d.s. (30) } & 43^{2} & \\ 1=\text { Number of patients. } & & \\ 2=\text { Results after six weeks. Other series after five weeks. }\end{array}$

SUMMARY

Carbenoxolone sodium was administered to 50 ambulant patients with gastric ulcer, in a dosage of $50 \mathrm{mg}$. three times a day for six weeks. The course was repeated if the ulcers failed to heal or recurred. After 70 courses of treatment, side effects had been observed in only three patients, who exhibited oedema or a rise of diastolic pressure of $20 \mathrm{~mm} . \mathrm{Hg}$ or more. One of the patients developed congestive cardiac failure while on the drug and died of a stroke 10 days after discontinuing it. All three patients were initially hypertensive, and were over 60 years of age.

The mean serum potassium level in 32 subjects on the last day of treatment was $4.1 \mathrm{mEq} / / \mathrm{l}$., and the mean fall in 18 subjects was $0.3 \mathrm{mEq} . / 1$.

Carbenoxolone sodium in this dosage is a safe drug in normotensive subjects in the absence of chronic cardiac, renal, or hepatic disease. Its therapeutic value in this dosage had yet to be proved, but the short-term effect on the ulcer niche in this series is encouraging.

I am grateful to Dr. I. H. Lawrence, Dr. D. J. Manton, and Dr. K. Mendl for their close cooperation in the Radiology Department, and to Dr. W. M. Philip for the referral of many cases.

\section{REFERENCES}

Doll, R., Hill, I. D., and Hutton, C. F. (1965). Treatment of gastric ulcer with carbenoxolone sodium and oestrogens. Gut, 6, 19-24.

,,,--- and Underwood, D. J., II (1962). Clinical trial of a triterpenoid liquorice compound in gastric and duodenal ulcer. Lancet, 2, 793-796.

Horwich, L., and Galloway, R. (1965). Treatment of gastric ulceration. with carbenoxolone sodium: clinical and radiological evaluation. Brit. med. J., 2, 1274-1277.

Turpie, A. G. G., and Thomson, T. J. (1965). Carbenoxolone sodium in the treatment of gastric ulcer with special reference to sideeffects. Gut, 6, 591-594. 